WSRC-RR- $-91-890$

I DE92 040046

\title{
RE-EVALUATION OF THE EFFECTIVENESS OF THE CENTRAL A/M AREA RECOVERY WELL NETWORK (U)
}

by

\section{J. S. Haselow}

Westinghouse Savannah River Company

Savannah River Site

Aiken, South Carolina 29808

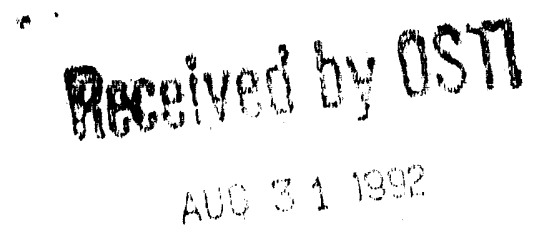

This report was prepared in connection with work done under Contract No. DE-ACOM-89S 218035 with the U.S. Department of Energy. By acceptance of this report, the publisher and/or recipient acknowledges the U.S. Government's right to retain a nonexclusive, royalty-free license in and to any copyright covering this report, along with the right to reproduce and to authorize others to reproduce all or part of the copyrighted report. 


\section{DISCLAIMER}

This report was prepared as an account of work sponsored by an agency of the United States Government. Neither the United States Government nor any agency thereof, nor any of their employees, makes any warranty, express or implied, or assumes any legal liability or responsibility for the accuracy, completeness, or usefulness of any information, apparatus, product, or process disclosed, or represents that its use would not infringe privately owned rights. Reference herein to any specific commercial product, process, or service by trade name, trademark, manufacturer, or otherwise does not necessarily constitute or imply its endorsement, recommendation, or favoring by the United States Government or any agency thereof. The views and opinions of authors expressed herein do not necessarily state or reflect those of the United States Government or any agency thereof.

This report has been reproduced directly from the best available copy.

Available to DOE and DOE contractors from the Office of Scientific and Technical Information, P.O. Box 62, Oak Ridge, TN 37831; prices available from (615) 576-8401, FrS 626.8401.

Available to the public from the National Technical Information Service, U.S. Department of Commerce, 5'85 Port Royal Rd., Springfield, VA 22161. 


\section{Re-Evaluation of the Effectiveness of the} Central A/M Area Recovery Well Network (U)

J. S. Haselow

Environmental Sciences Section

June, 1991

Authentication:

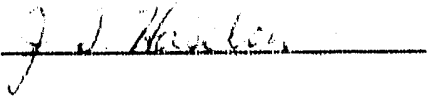

Approved By:

Dorane- Shedras.-

D. B. Moore, Section Maragci

Environmental Sciences Section

Savannah River Laboratory

WESTINGHOUSE SAVANNAH RIVER COMPANY

SAVANNAH RIVER LABORATORY

SAVANNAH RIVER SITE

AIKEN, SC 2.9808

Prepared for the U. S. Department of Energy under Contract No. DE-AC09-89SR 18035 


\section{EXECOTIVE BUMMARY}

A groundwater recovery well network has been operating in the central portion of the $\mathrm{A} / \mathrm{M}$ Area of the Savannah River Site (SRS) since 1985 to retrieve chlorinated volatile organic solvents. In 1986, a groundwater modeling study was performed to evaluate the effectiveness of the recovery well network that included planned recovery wells (RWM 1 through 11 ) and process water wells (S. $S$. Papadopulous, 19B6). Since the original modeling study, use of some of the process wells has discontinued and some pumping rates at other welis have changed. Also, the understanding of the hydrologic system in the $A / M$ Area has improved because additional monitoring wells have been installed in the area. As a result, an updated groundwater flow model (Beaudoin et al., 1991) for the area was used to evaluate the effectiveness of the existing recovery network. The results of this study indicate that the estimated effectiveness of the recovery weli has not changed dxamatically since the original groundwater modeling study. However, slight differences do exist between the original study and this study because the recent model more accuratily reflects the $A / M$ Area subsurface hydrologic system. 
TABLE OF CONTENTS

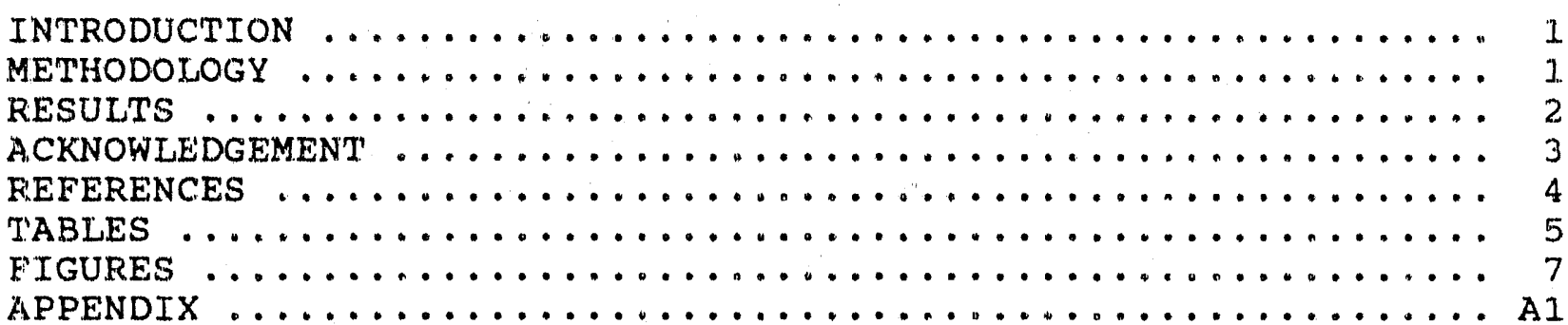

\section{IIBI OF TALISS}

Table 1. Historical pumping Rates for A/M Area Wells ....... 5

Table 2. Recent Pumping Rates for A/M Area Wells ......... 6

\section{IIST OF FIGURES}

Figure 1.

Figure 2,

Figure 3.

Figure 4 .

Figure 5.

Figure 6 .

Figure 7.
Areal Discretization of Model Area .........7 7

Zone of Capture for the water Table

(Total Recovery Well Pumping of $427 \mathrm{gpm}$ ) .... 8

Zone of Capture for the Upper Congaree

(Total Recovery Well Pumping of $427 \mathrm{gkm}$ ).... 9

zone of Capture for the Lower congaree

(Total Recovery Well Pumping of $427 \mathrm{gpm}$ ) ..... 10

Zone of Capture for the water Table

(Total Recovery Well Pumping of $508 \mathrm{gpm}$ ) .... 11

Zone of Capture for the Upper congaree

(Total Recovery Well Pumping of $508 \mathrm{gpm}$ ) ..... 12

zone of Capture for the Lower congaxee

(Total Recovery Well Pumping of $508 \mathrm{gpm}$, .... 13 


\section{INTRODUCTION}

A recovery well network has been operating in the central portion of the $A / M$ Area of the Savannah River Site (SRS) since 1985 to remove trichloroethylene (TCE) and perchloroethylene (PCE) from groundwater. In 1986, a groundwater modeling study was performed to evaluate the effectiveness of the existing recovery and process water wells (S. S. Papadopulous, 1986). Since the original modeling study, use of some process wells has discontinued and some pumping rates at other wells have changed. Also, the understanding of the hydrologic system in the $A / M$ Area has improved. As a result, the groundwater flow model for the area was updated (Beaudoin et al., 1991). This revised model was used in conjuction with particle tracking to re-evaluate the effectiveness of the existing recovery network. The results of this particle tracking study are also reported in the part B post closure Permit for the M-Area Hazardous Waste Management Facility (1990).

This report is a particle tracking and zone of capture study only. The reader who is interested or requires the details of the flow model that was used for the basis of this study is directed to Beaudoin et al., 1991.

\section{METHODOLOGY}

A calibrated steady-state groundwater flow model was used in conjuction with particle tracking to determine the effectiveness of the recovery network. Particle tracking is an effective method to evaluate the performance of a recovery well system without completing a more-costly contaminant transport simulation. particle tracking is completed by simulating the backward paths of a distribution of particles emanating from the circumference of a well. The mathematical conceptualization of this approach is piece-wise time integration of the negative of the velocity field. The particle tracking method allows one to determine the hydrologic control of a plume and estimate the region of water that is recovered by the network during a specific time period. For this study, the particle tracking method incorporated advection only and did not account for mechanical dispersion or retardation. However, equilibrium-type retardation can be accounted for by increasing the zone of capture time directly proportional to the retardation coefficient. The effective porosity for this study was set equal to 30 percent, which is believed to be conservatively high.

The MODFLow code was used to simulate the steady-state groundwater flow system for the area (McDonald and Harbaugh, 1984). The MODFLOW code is a quasi-three-dimensional groundwater flow computer code. That is, the vertical flow between aquifers is incorporated with a leakance coefficient, and the aquitards 
are therefore not discretized. The modeled system consists of four water bearing units. From top to bottom, these units have been informally named the water table, the Upper congaree, the Lower Congaree, and the Black Creek. The Elienton was not discretized as an aquifer because it is mainly lenses of clay and does not have substantial water production capacity. It is recognized that these names do not adhere to the formal hydrostratigraphic nomenclature used for the SRS (Aadland and Bledsoe, 1991), but they were maintained to allow comparison to the previous modeling effort. steady-state simulations of a coarse-grid model for the entire $A / M$ Area were run to determine the hydrologic parameters for the system that adequately reproduced the observed average hydraulic heads (1089 to 1090) for the area (Beaudoin et al., 1991). The calibrated values of transmissivity, leakance coefficient, and recharge for the model domain are given in Appendix A. These parameters are within the range of those determined from aquifer tests and grain size analyses. This coarse-grid model was used for the basis of the particle tracking, but the grid was refined in the central. region, so that wells could be placed at a node close to its true location, and to minimize numerical exrors in the particle tracking used for the zone of capture analysis. The refined areal discretization varied from 125 to 1000 feet and is shown in Figure 1 .

The pumping rates for the wells within the model domain are given in Tables 1 and 2. Two simulations were completed; one for pumping rates totaling 425 gpm for the eleven dedicated recovery wells (RWM 1 through RWM 11), and one totaling $507 \mathrm{gpm}$ for the eleven recovery wells. The former total pumping rate represents an average withdrawal that has been used over the past few years, while the latter pumping rate represents the recent increase in total pumping rate for the dedicated recovery wells.

\section{RESULTS}

The results of the zone of capture analysis for the recovery wells RWM 1 throuxh RWM 11 pumping at a total of $425 \mathrm{gpm}$ are shown in Figures 2,3 , and 4 for the water table, upper congaree and Lower congaree, respectively. There is a slight difference between these figures compared to those of Papapopulous (1986) for the Upper congaree and water table for two reasons (Appendix B). The first reason for the difference is that some process welis are not operating any longer ( $\mathrm{PW}-98, \mathrm{PW}-99)$ and some of the flow rates at the recovery wells have changed. The second reason is that the Papadopulous $(1986)$ groundwater flow model used noflow boundaries at all exterior edges of the model. Because there is no way for water to flow into the system other than through recharge with this type of boundary, Papadopulous (1986) replaced the water removed through pumping with an artificially high recharge to the surface of the water table within the zone 
of influence of the wells. Papadopulous was forced to add recharge in this manner so that the simulated hydrologic system did not become dry. The result of this modeling assumption is that more water is moving vertically through the area of pumping than is realistically occurring.

The difference for the Lower congaree zone of capture for this study and Papadopoulous is more pronounced. This is because the difference in the pumping rate for the production wells which was "pulling" groundwater down and preventing it from being captured by the recovery wells screened in the Lower Congaree.

The results of the zone of capture analysis for the recovery wells RWM 1 through RWM 11 pumping at a total of $507 \mathrm{gpm}$ are shown in Figures 5, 6, and 7 for the water table, Upper Congaree and Lower Congaree, respectively. The distribution of the pumping to the recovery wells is shown in Table 2 . This greater pumping rate reflects the recent increase in the pumping rates of the recovery well.s. As can be seen by comparing Figures 2 through 4 with Figures 5 through 7 , the simulated zone of capture is only slightly improved by the increased pumping, because the pumping increase as distributed over three hydrologic units is not significantly greater and the recovery well system relies on the direction of natural flow in the system, which is not significantly affected by the pumping of the wells.

However, the system as currently operating is controlling and recovering the central portion of the $A / M$ Area plume. Additional modeling has been performed for a SRL recovery well network, and more is planned for the "southern sector." After the southern sector modeling is performed, an integrated zone of capture model will be completed to evaluate the integrated recovery system for the entire $\mathrm{A} / \mathrm{M}$ Area.

\section{ACKNOWLEDGEMENT}

Mark Schwartz of Schreuder \& Davis Inc. completed the drafting of the figures for the zone of capture analyses for this report. 


\section{REFERENCES}

Aadland, R.K., and H.W. Bledsoe, 1990. Classification of Hydrostratigraphic Units at the Savannah River Site, South Carolina. WSRC-RP-90-987. Westinghouse Savannah River Company, Aiken, SC.

Beaudoin, C.M., P.J. Schrueder, and J.S. Haselow, 1991. A Ground Water Flow Model for the A/M Area of the SRS (U), WSRC-RP-910585 .

McDonald, M.G. and A. W. Harbaugh, 1984. A Modular Threedimensional Finite-Difference Ground-Water Flow Model, United states Geological Survey, Reston, Virginia.

S. S. Papadopulous, 1986. Evaluation of the Effectiveness of the M-Area Extroction System, Report prepared for the Savannah River Site, Aiken, ic. 


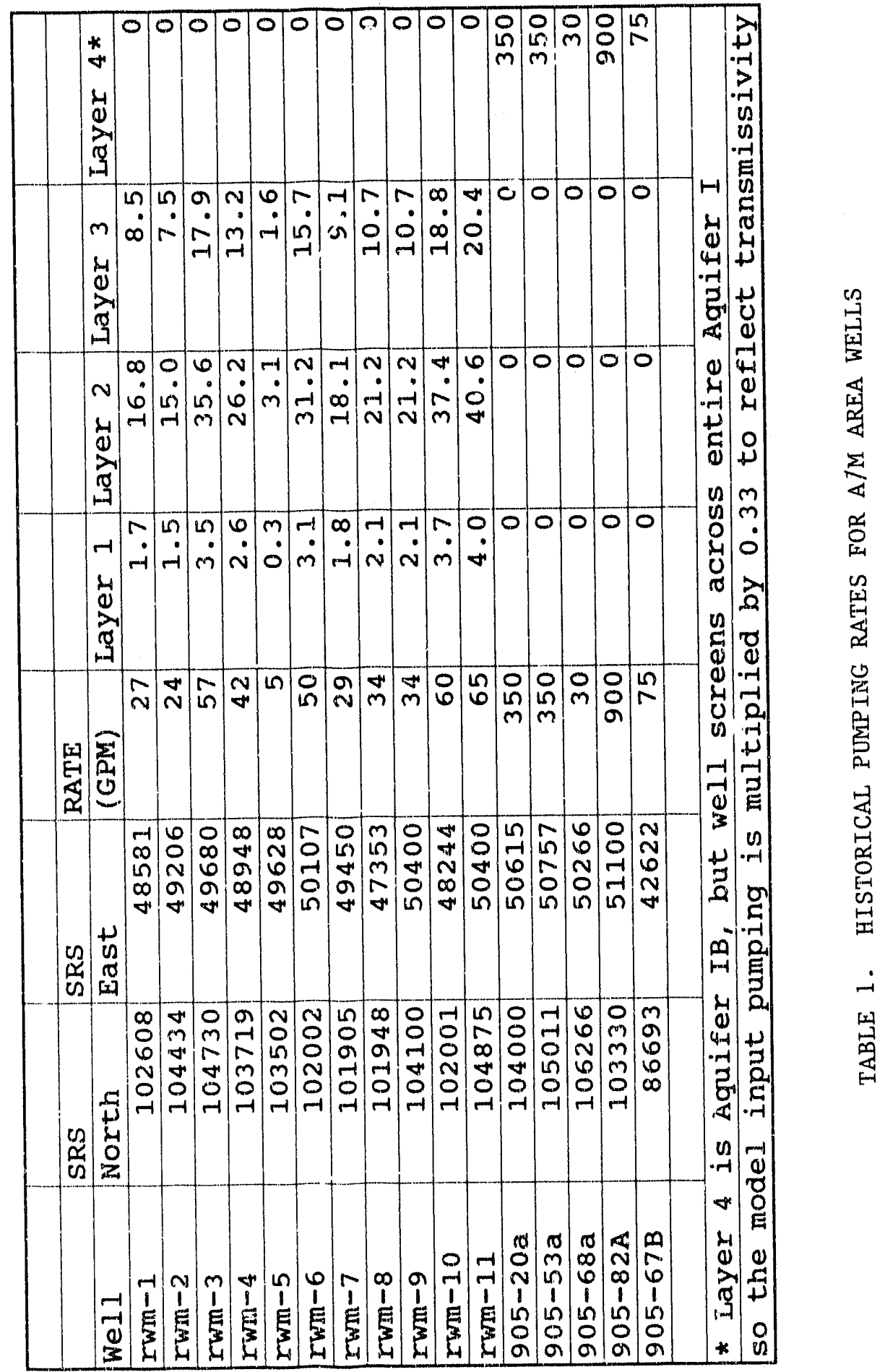




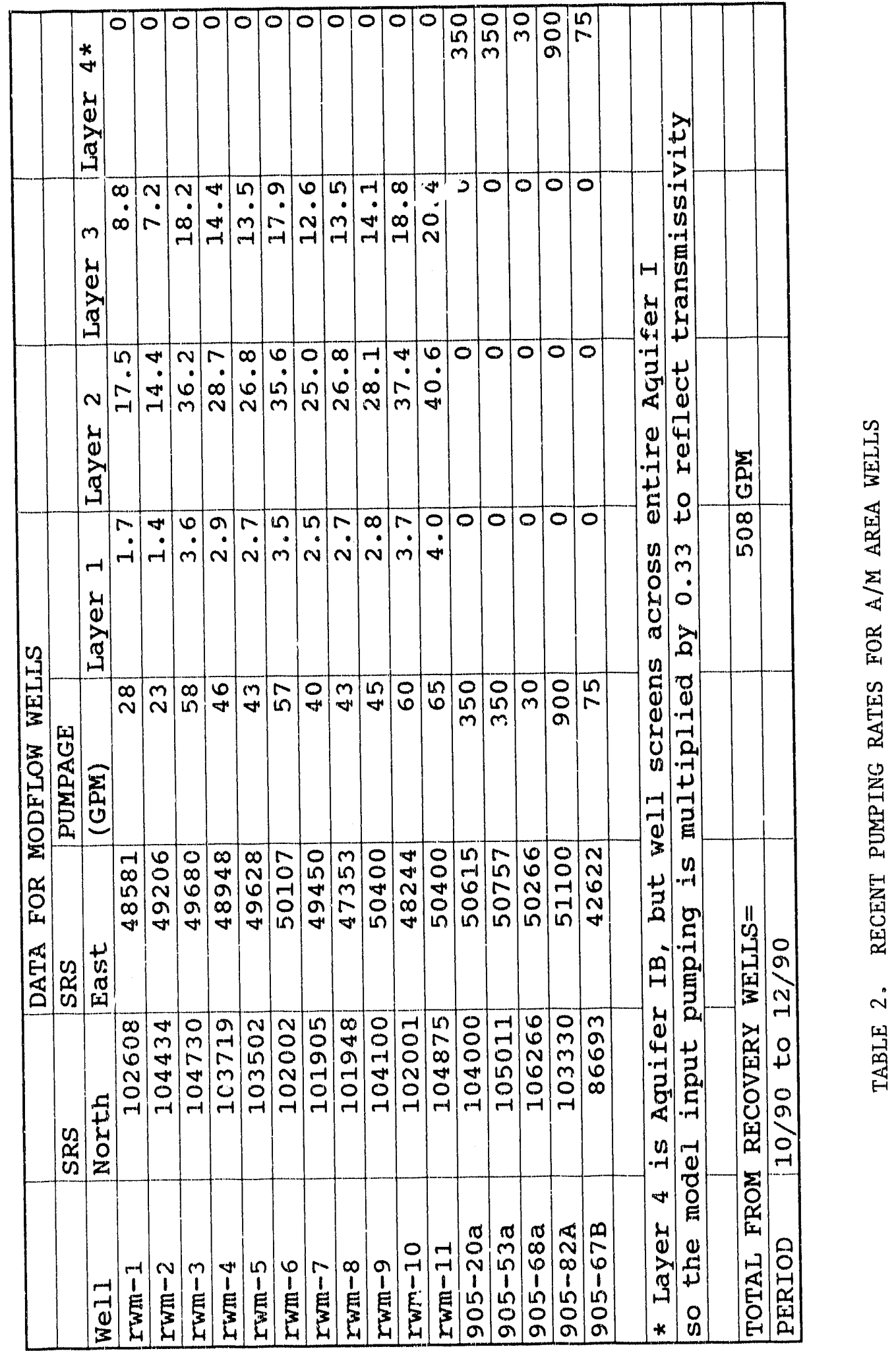


FIGURE 1: AREAL'DISCRETIZATION OF MODEL ÁREA

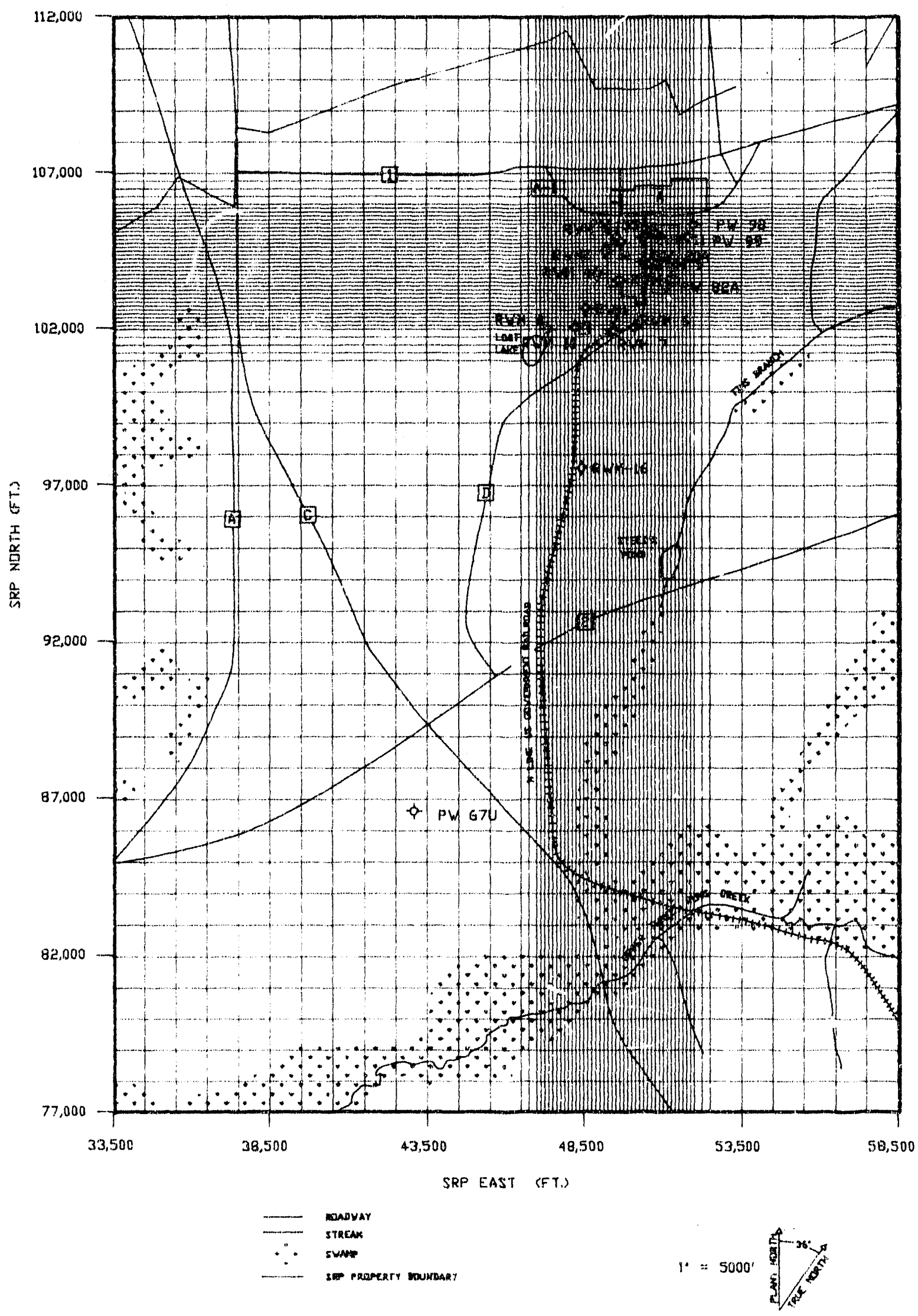


WATER TABLE

QMOUND WATER CAPTUAE ZONE

FIGURE 2: ZONE OF CAPTURE FOR THE WATER TABLE

(TOTAL RECOVERY WELL PUMPING OF 427 GPM)

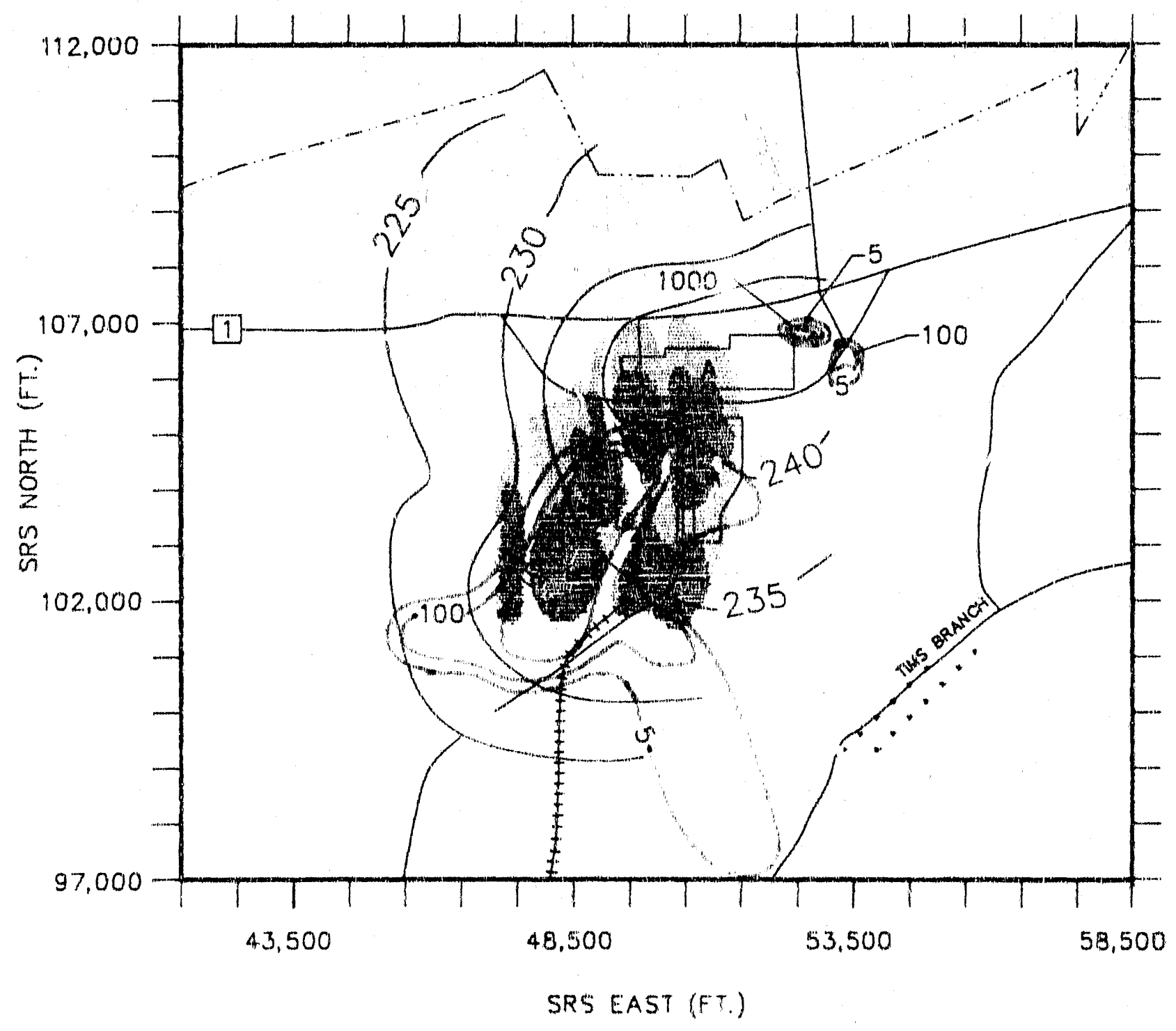

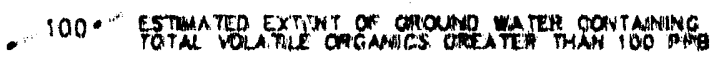

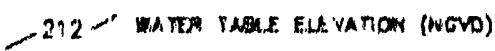

- mecovenir meu.

-.... ronutur

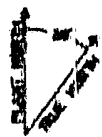

$\therefore$ swanup

- i- sar pacaertr gocikbanar

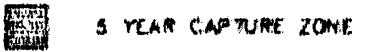

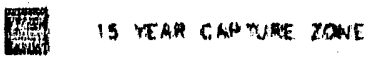

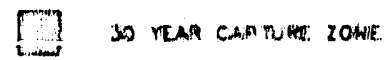

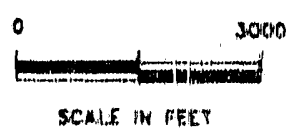

7/8/A9 


\section{UPPER CONGAREE \\ GROUND WATER CAPTURE ZONE}

FIGURE 3: ZONE OF CAPTURE FOR THE UPPER CONGAREE

(TOTAL RECOVERY WELL PURAPING OF 427 GPM)
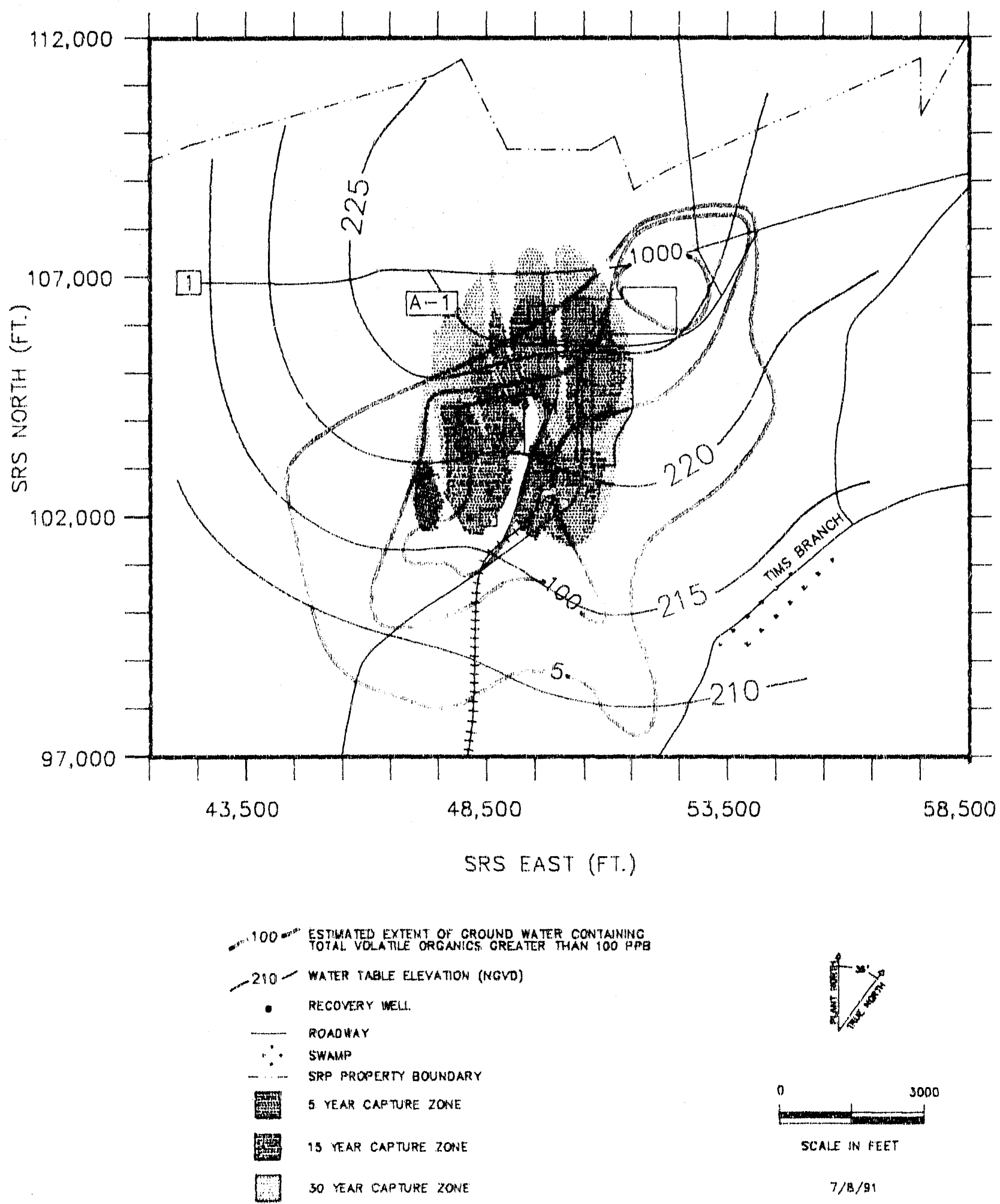

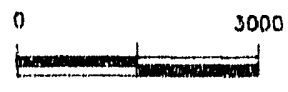

SCALE IN FEET

$7 / 8 / 91$ 


\section{OWEA CONGAAEE \\ GRULND WATEA CAPTURE ZONE}

FIGURF 4: ZONE OF CAPTURE FOR THE LOWER CONGAREE

(TOTAL RECOVERY WELL PUMPING OF 427 CPM)

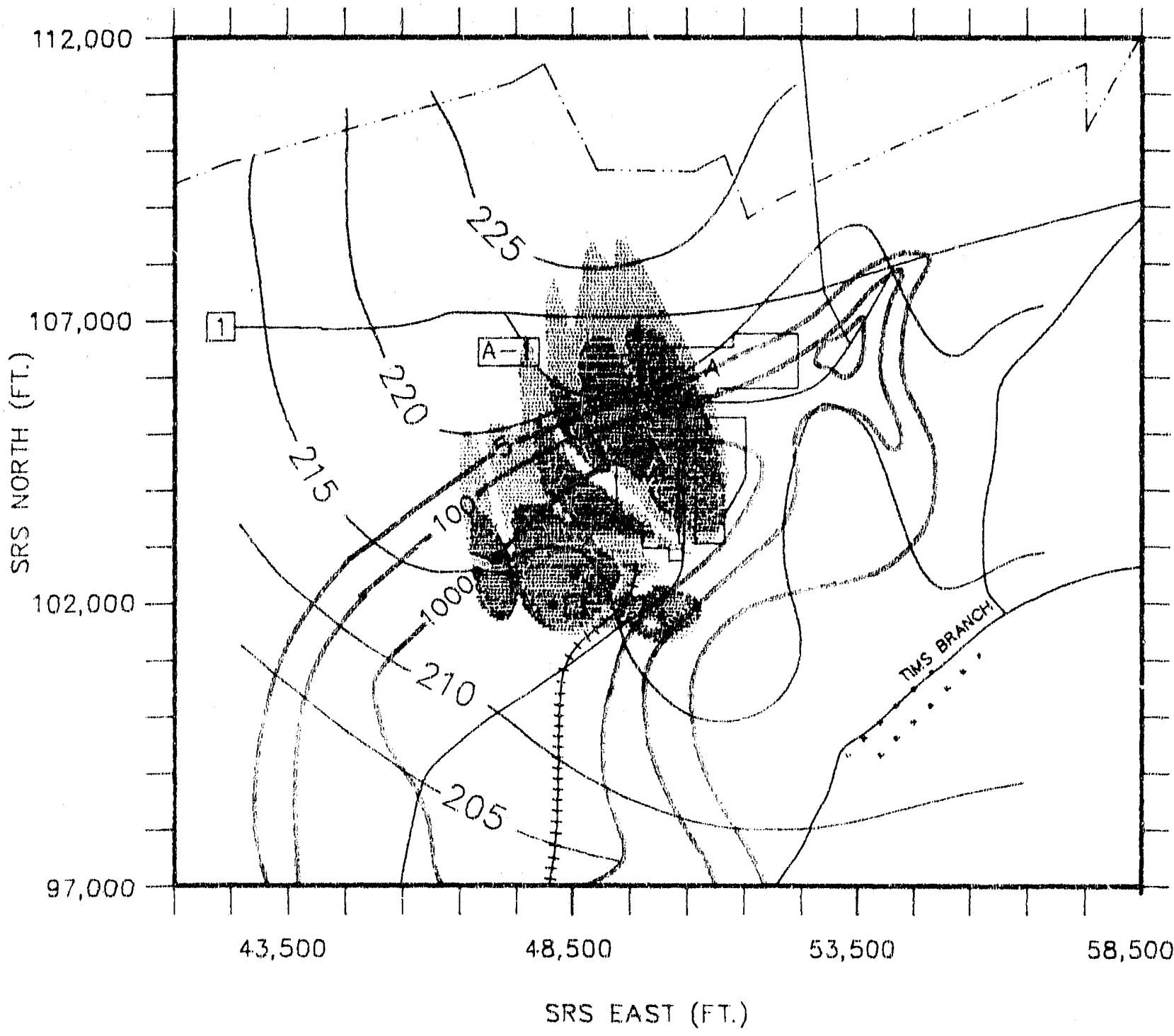

- 100 - FSTIMATED EXTENT OF CROUND WATER CONTANING
TOTAL VOLATLE OHCANICS GREATER THAN 1 OOO PPB

-19.5 WATER TABLE ELEVATON (NOVD)

- recoverr mel

- rondwar

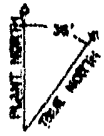

$\therefore$ swamp

-..- SRP PRDPEERTY GOUNDAR

W TEAR CAPRURE ZDNE

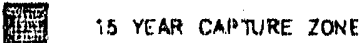

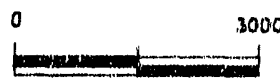

SO TEAR CAPTURE ZONE

SCALE IN FE,T

$7 / 8 / 81$ 


\section{WATER TABLE \\ GAOUND WATER CAPTIAE ZOWE}

FIGURE 5: ZONE OF CAPTURE FOR THE WATER TABLE

(TOTAL RECOYERY WELL PUMPING OF 508 GPM)

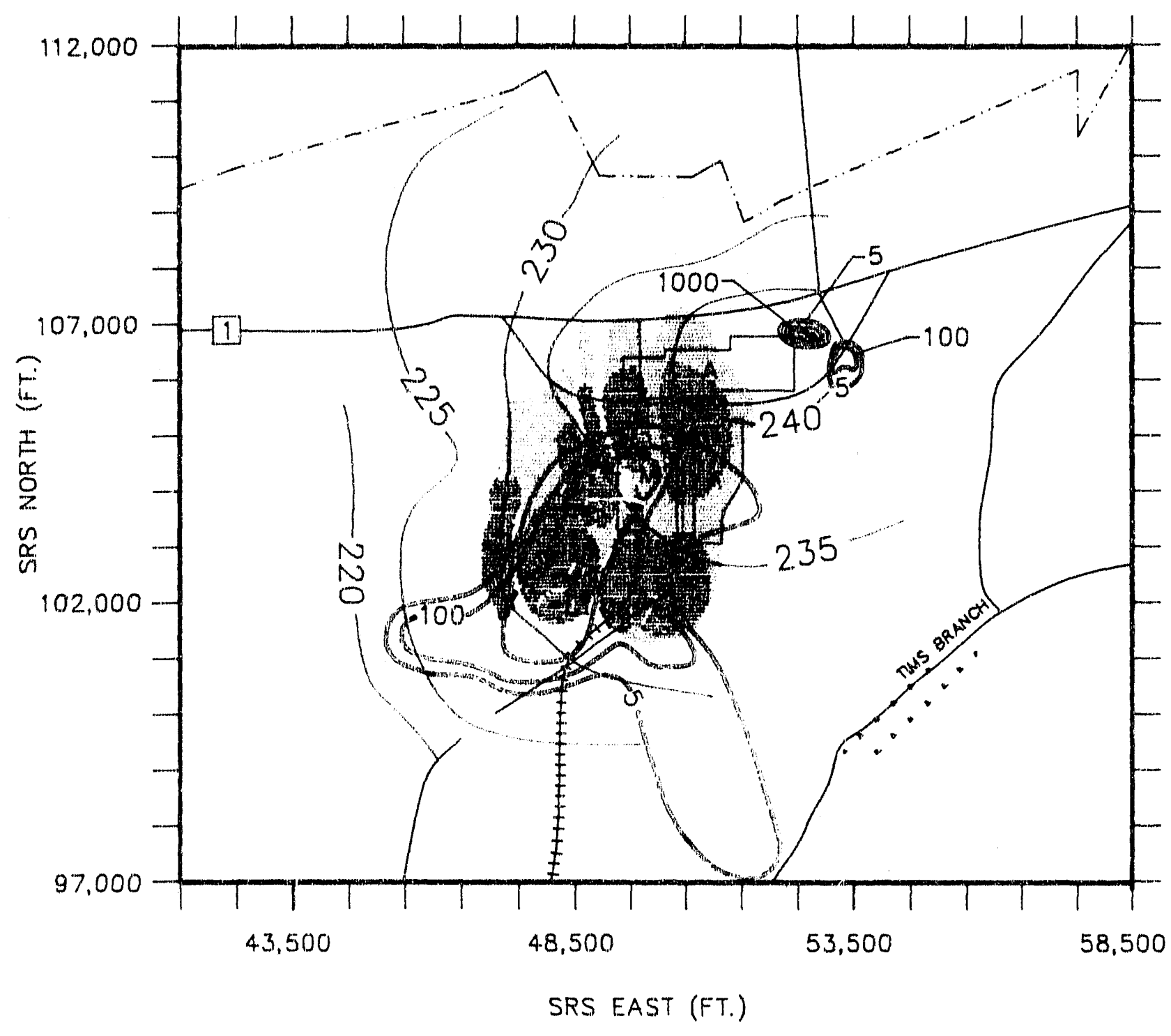

- 100 ESTUA TED EXTENT OF GRQUND WATTER CONTANING

212- WATER tABLE ELEVATOM (NOVO)

- recovery wel.

monuwar

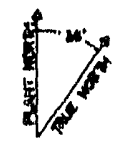

$\because \quad$ SWAMP

.... - SRP PRDPERTY BOUNDARY

I YEAR CAPTURE ZONE

IS VEAR CAPTUAE ZONE

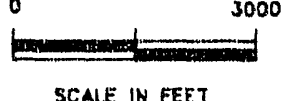

30 TEAA CAAPTURE ZONE

$1 / 27 / 01$ 


\section{UPPEA CONQAREE \\ CROUND WATEA CAPTUAE ZONE}

FIGURE 6: ZONE OF CAPTURE FOR THE UPPER CONGAREE

(TOTAL RECOVERY WELL PUMPING OF 508 GPM)

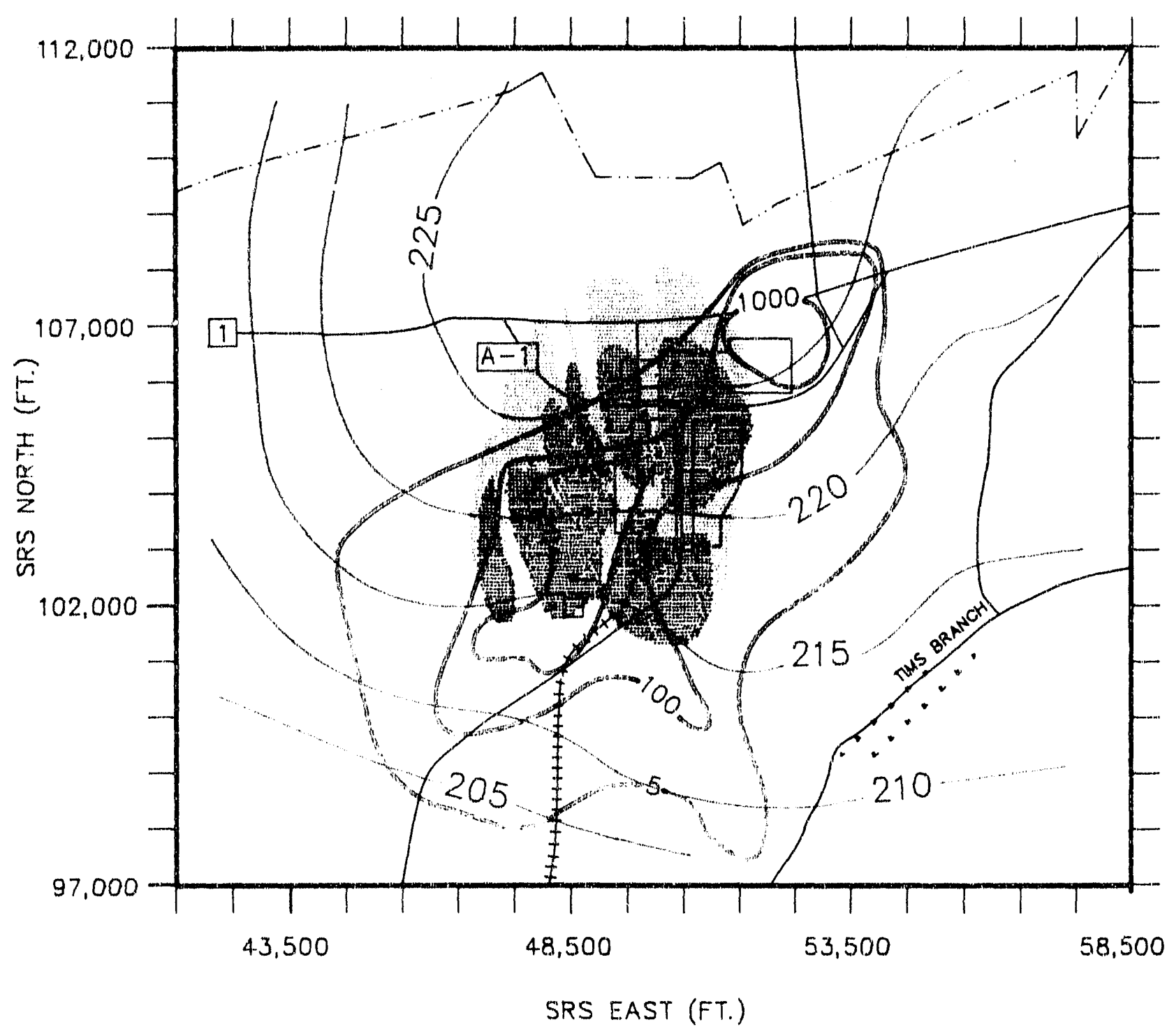

100 ESTMATED EXTENT OF GROUND WATER CONTAINING
TOYAL VOLATLE DRGANICS GREATER THAN 100 PFE

210 WATER TABLE ELEVATION (NGVD)

- Recovery weLl

- ronovaY

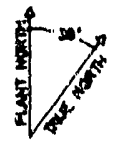

$\because$ SWAMP

- $\cdots$ SRP PROPERTY GOUNDARY

FTEA TEAR CAPTURE ZONE

I5 TEAR CAPTURE tone

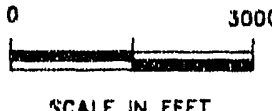

30 yeAR CAPTURE zone

$6 / 27 / 91$ 


\section{LOWER CONGAREE \\ GROUND WATER CAPTUAE ZOME}

FIGURE 7: ZONE OF CAPTURE FOR THE LOWER CONGAREE

(TOTAL RECOVERY WELL PUMPING OF 508 GPM)

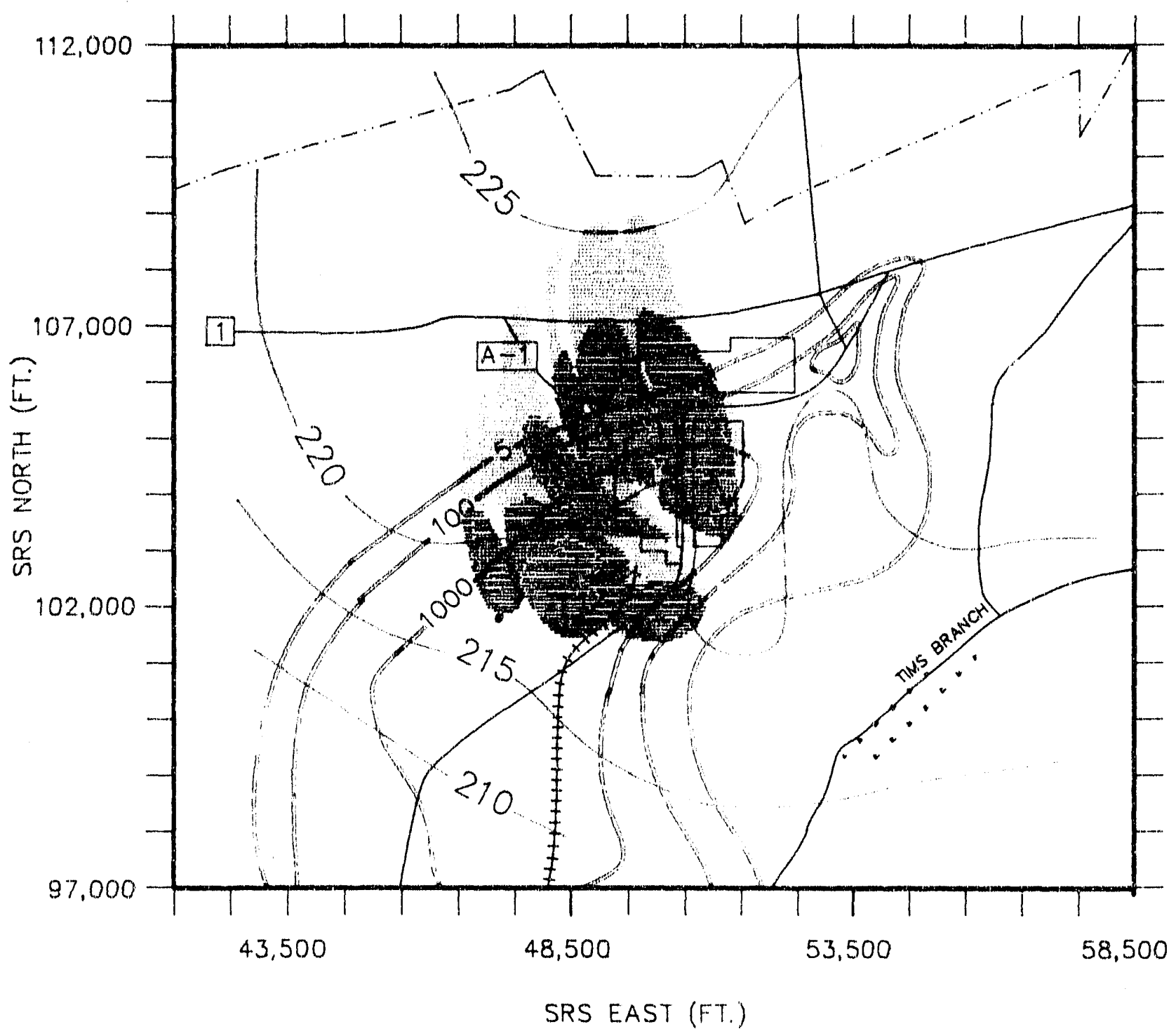

\% 100 ESTIMATEO EXTENT OF GROUND WATER CONTAININC

195. WATER TAELE ELEVIITON (NGVO)

- recovery well

- rondway

$\because$ swamp

- - SRP PROPERTY BOUNDARY

I TEAR CAPTURE ZDNE

HOH YEAR GAPTURE ZONE

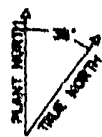

T30 VEAR CAPTURE ZONE

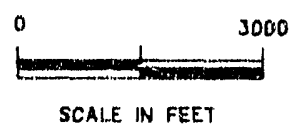

$6 / 27 / 21$ 
APPENDICES 


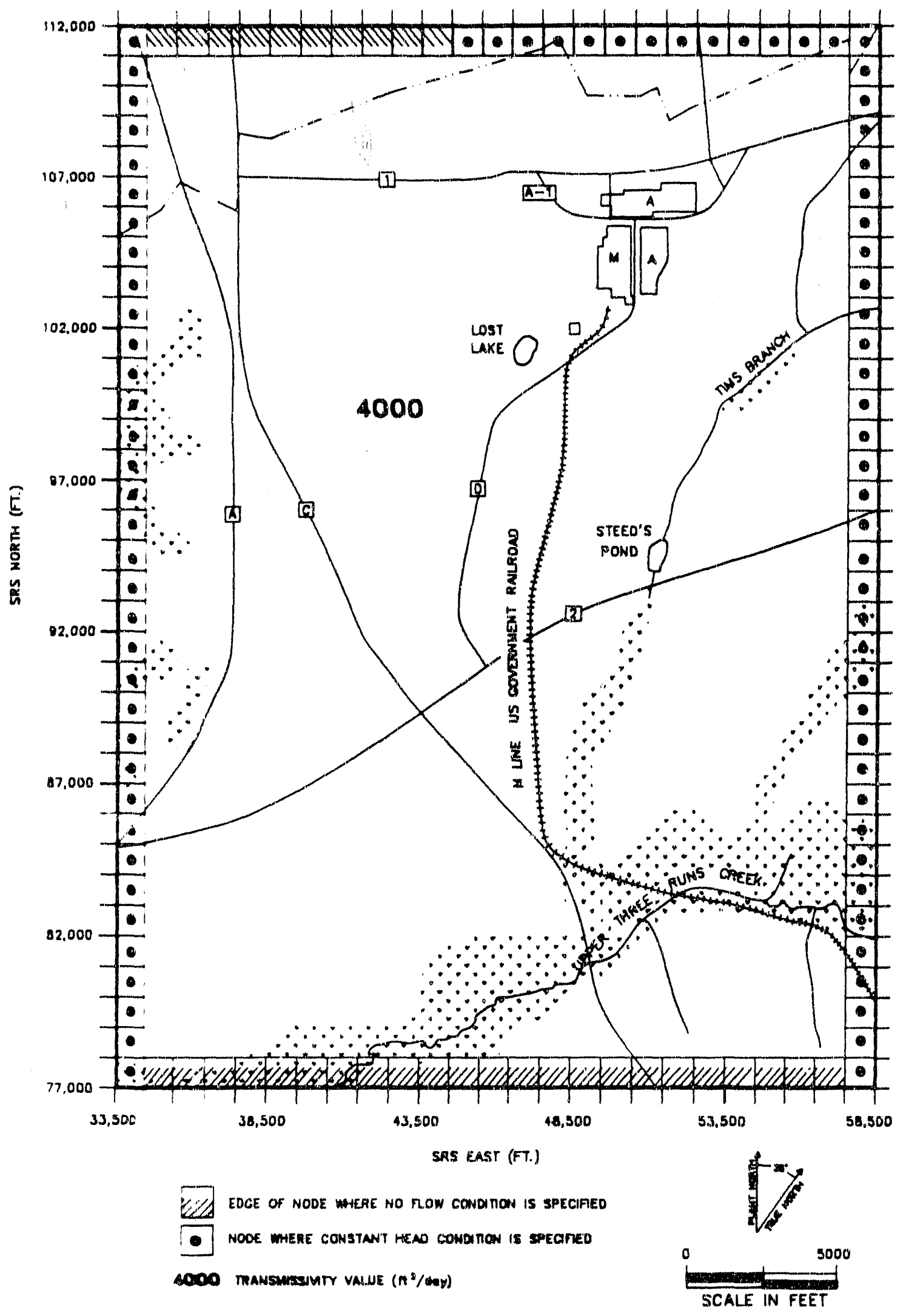

Figure 18. Boundary Conditions and Transmissivity in Model Layer 4.

A Ground Hater Flow Model for the A/M Area of the SRS (U) 


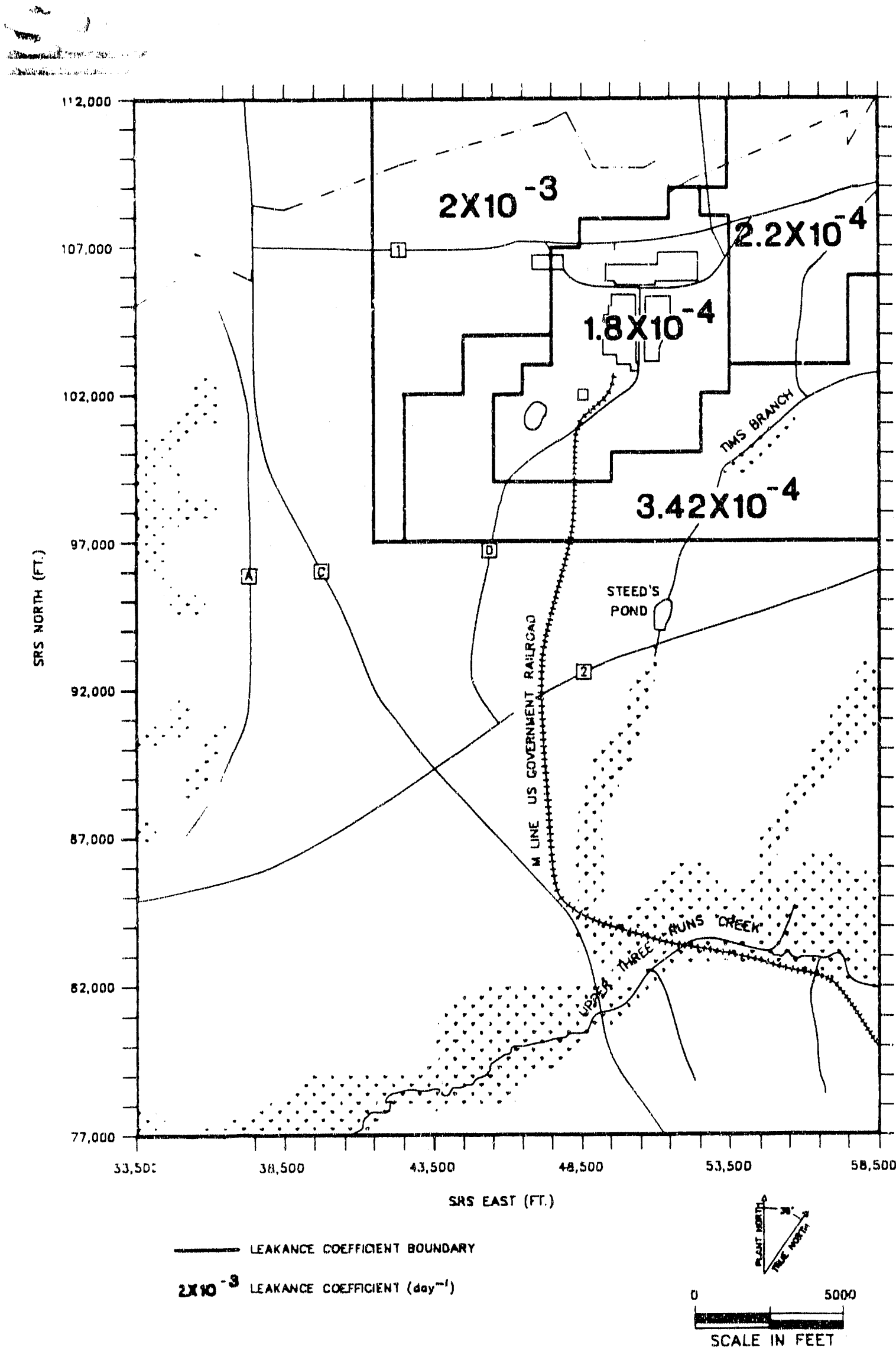

Figure: $9 . \quad$ Calibrated Leakance Map for Model Layer 1.

A Grovid Hater Flow Model for the A/M Area of the SRS (U) 


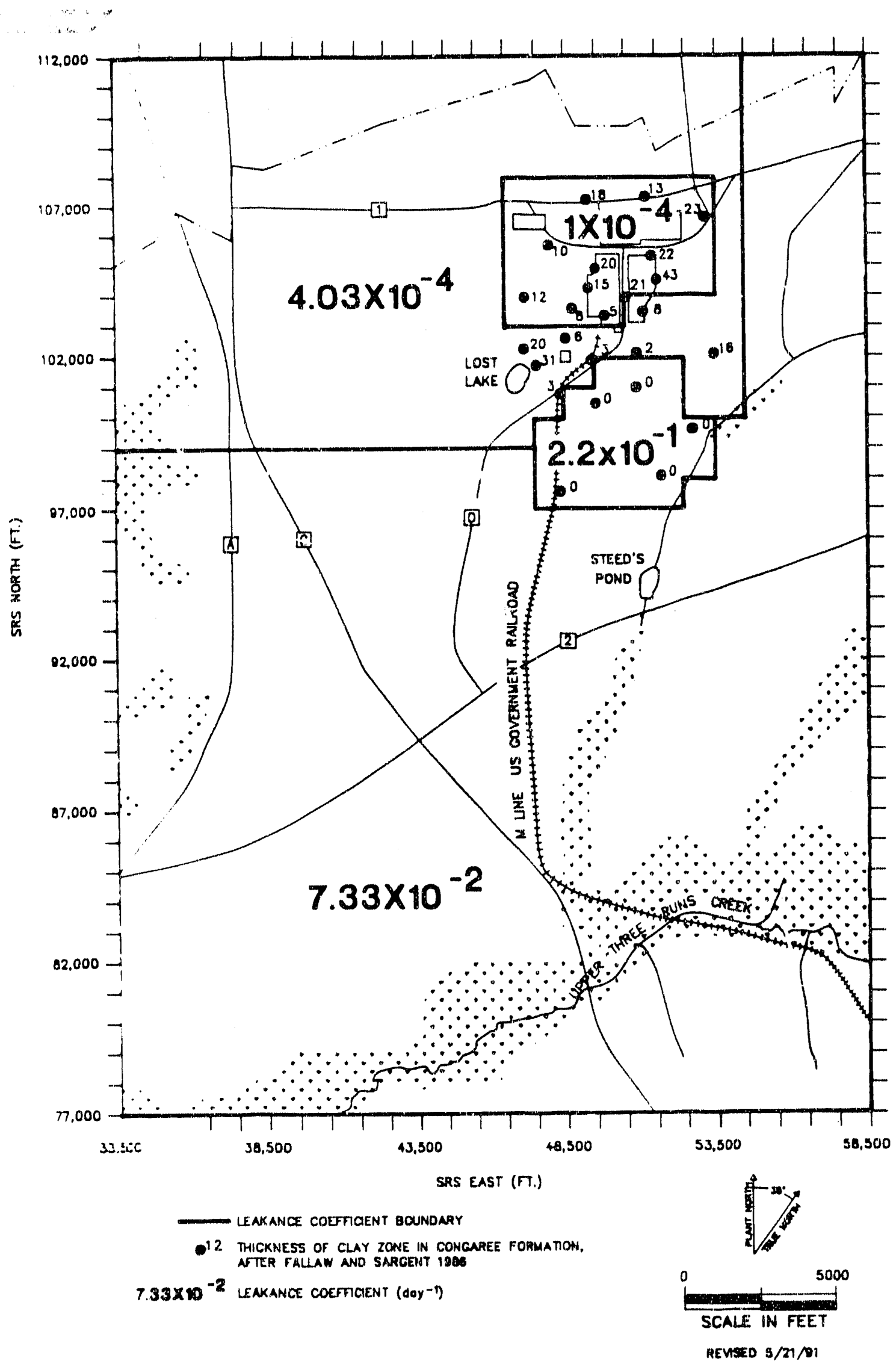

Figure $=0 . \quad$ Calibrated Leakance Map for Model Layer 2.

A Ground Hizter Flow Model for the A/M Area of the SRS (U) 


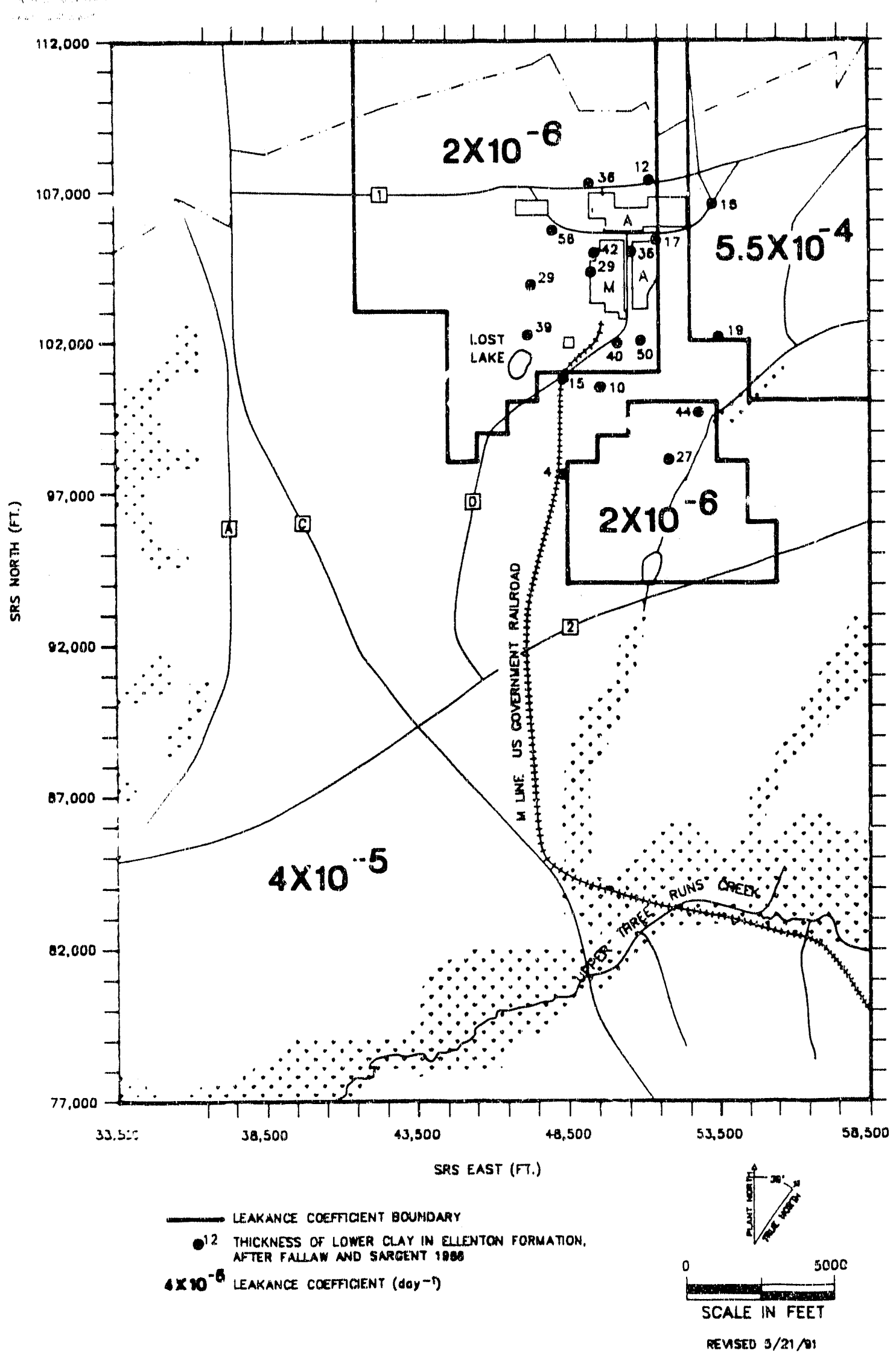

Figure:- Calibrated Leakance Map for Model Layer 3. 


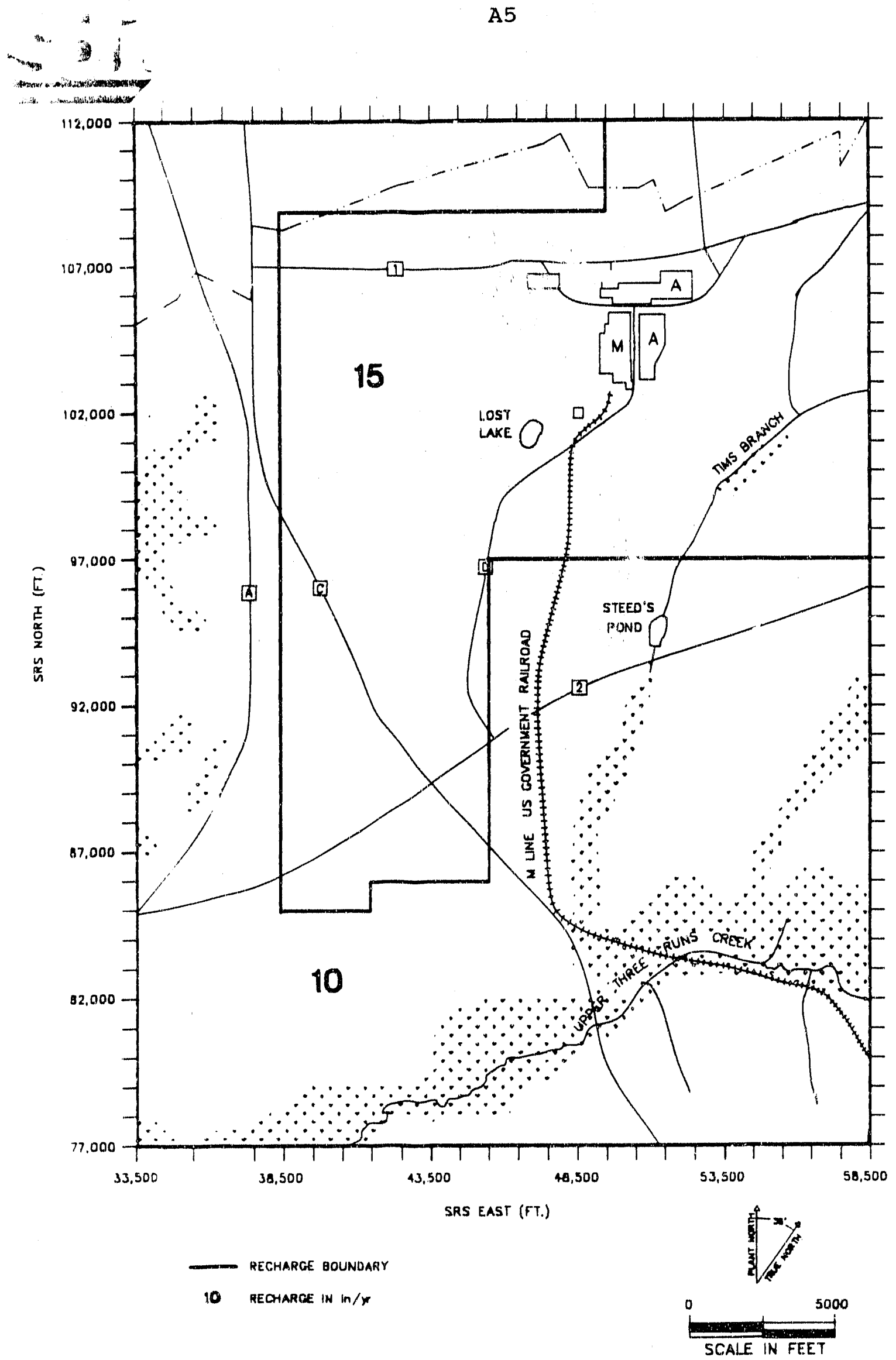

Figure 22. Modeled Rainfall Recharge.

A Ground Hater Flow Model for the A/M Area of the SRS (U) 
10.

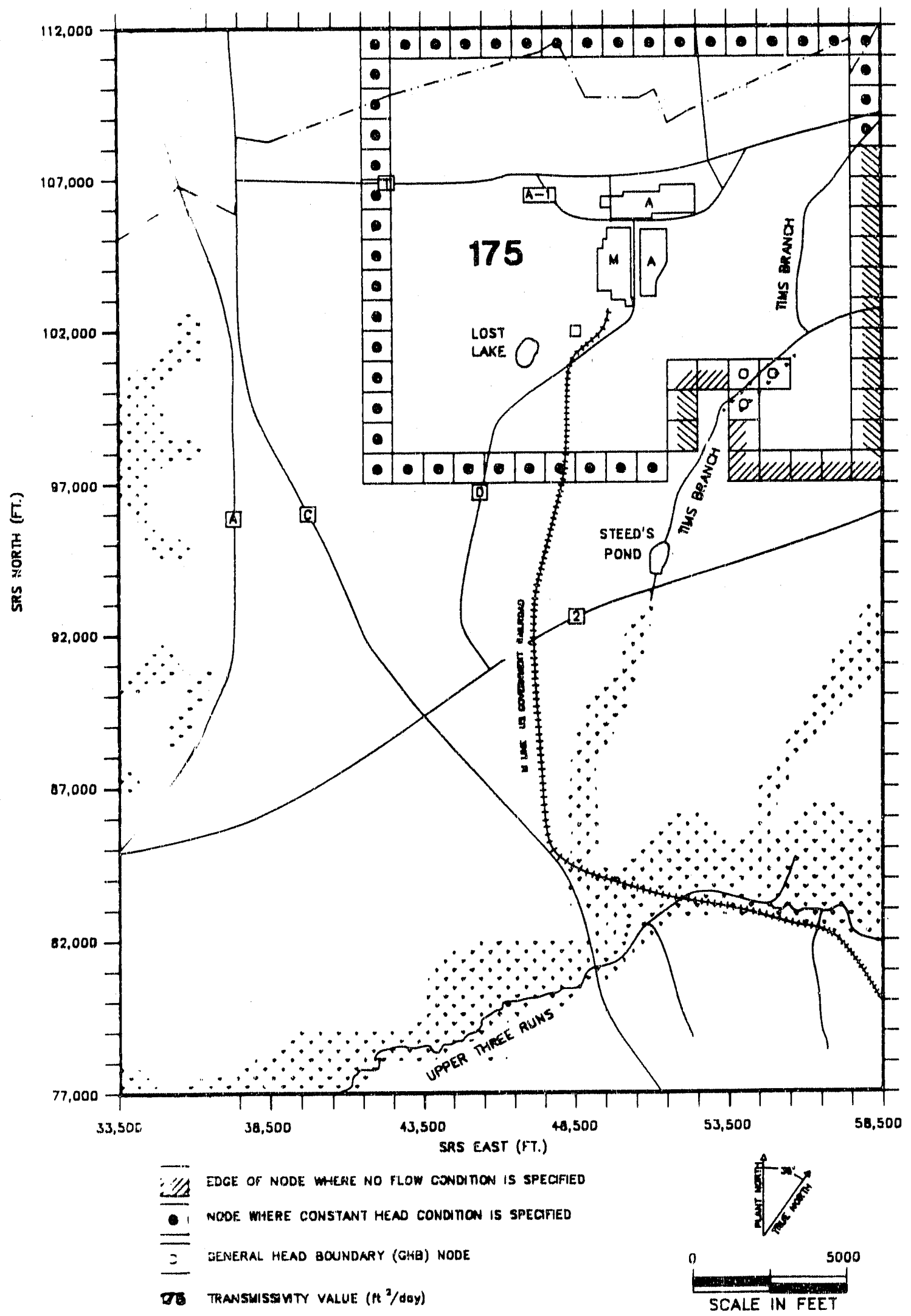

Figure 15. Boundary Conditions and Transmissivity in Model Layer 1.

A Groud Hater Flow Model for the A/M Area of the SRS (U) 


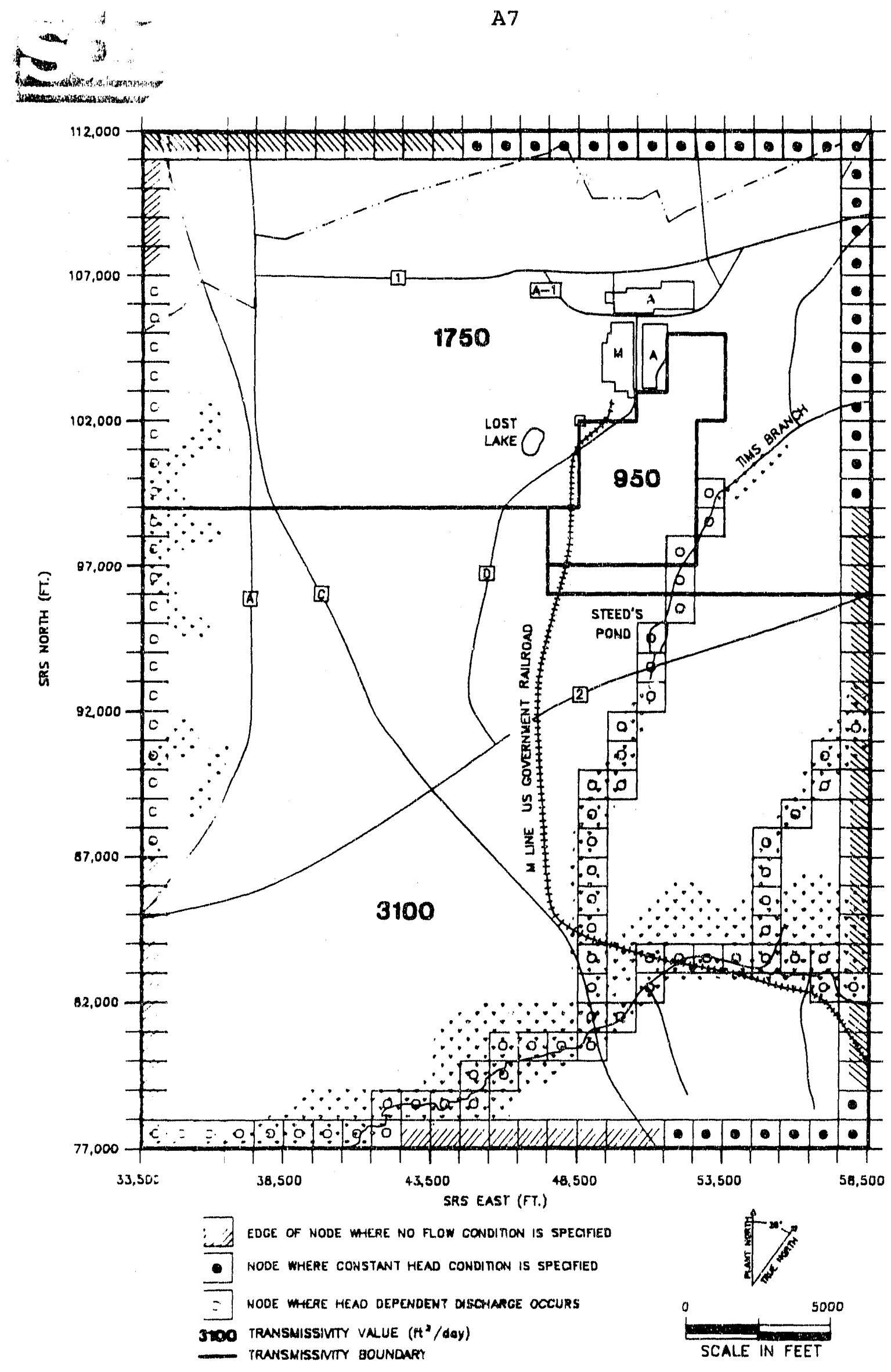

Figure 16. Boundary Conditions and Transmissivity in Model Layer 2.

A Gruad in ater Flow Mlodel for the A/M Area of the SRS (U) 


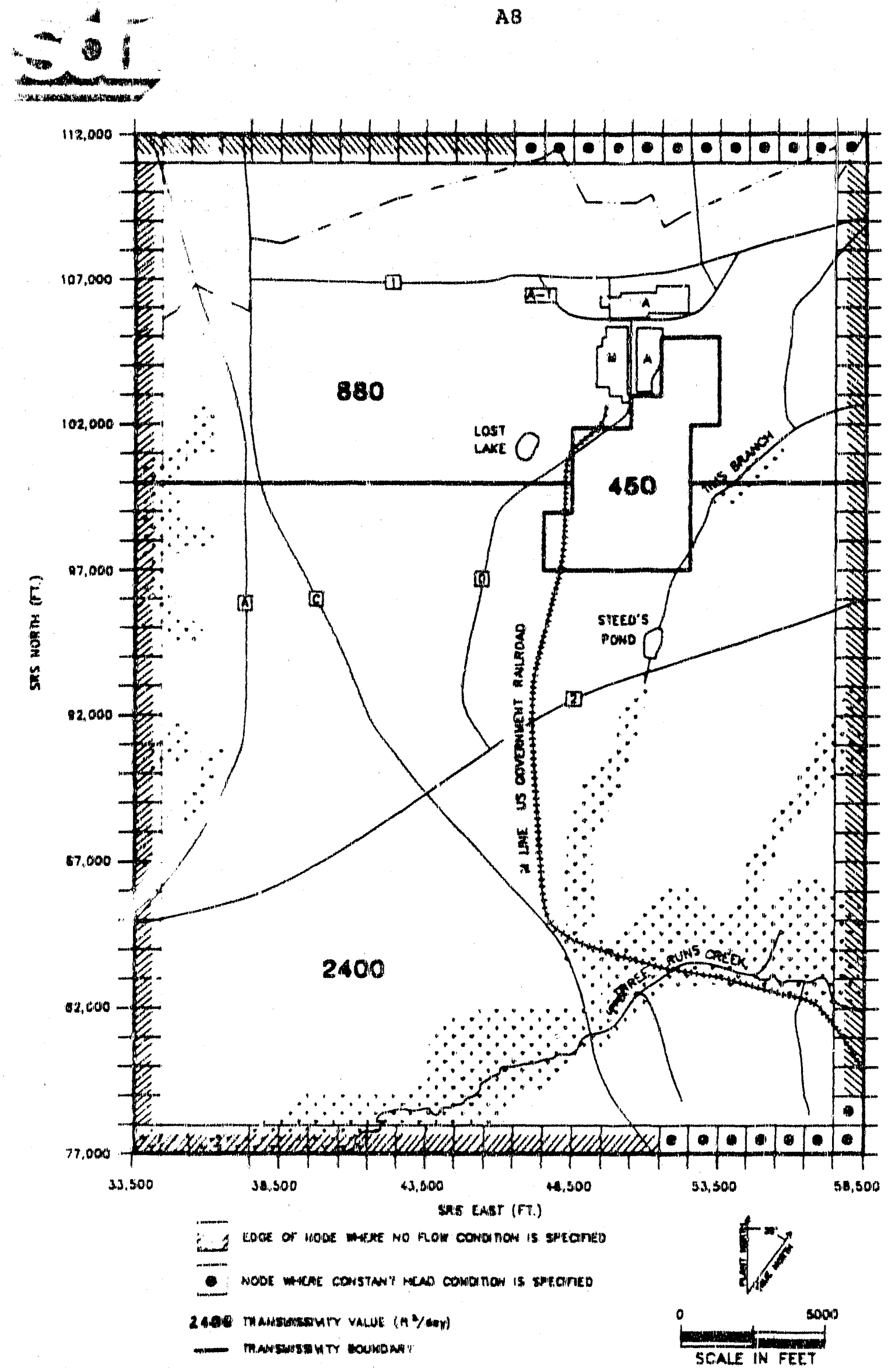

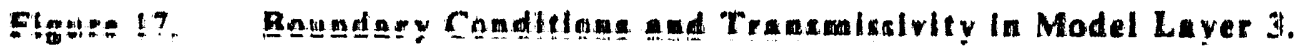

A Ground Weter Flow Model for the A/M Area of the SRS (U) 


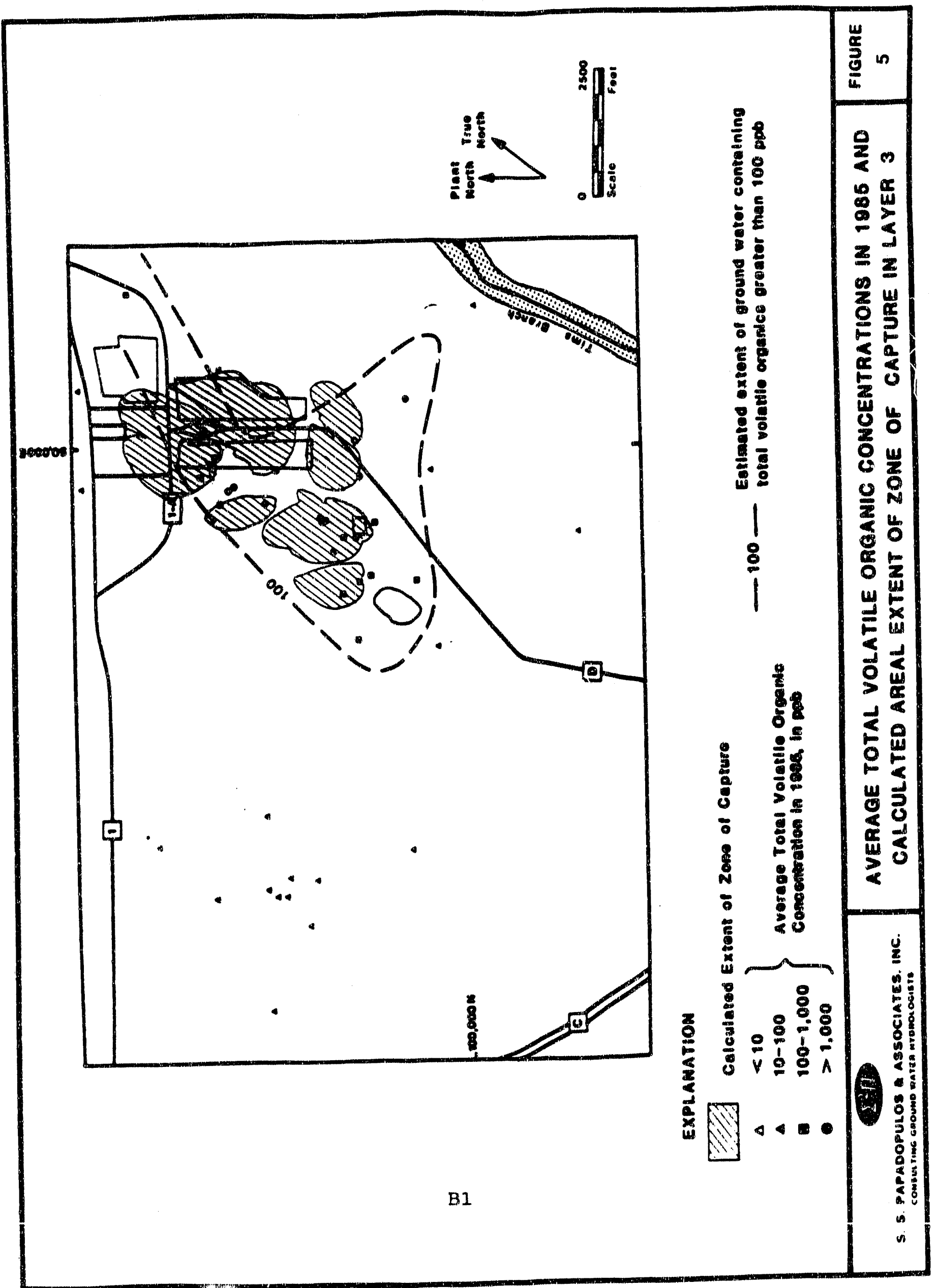




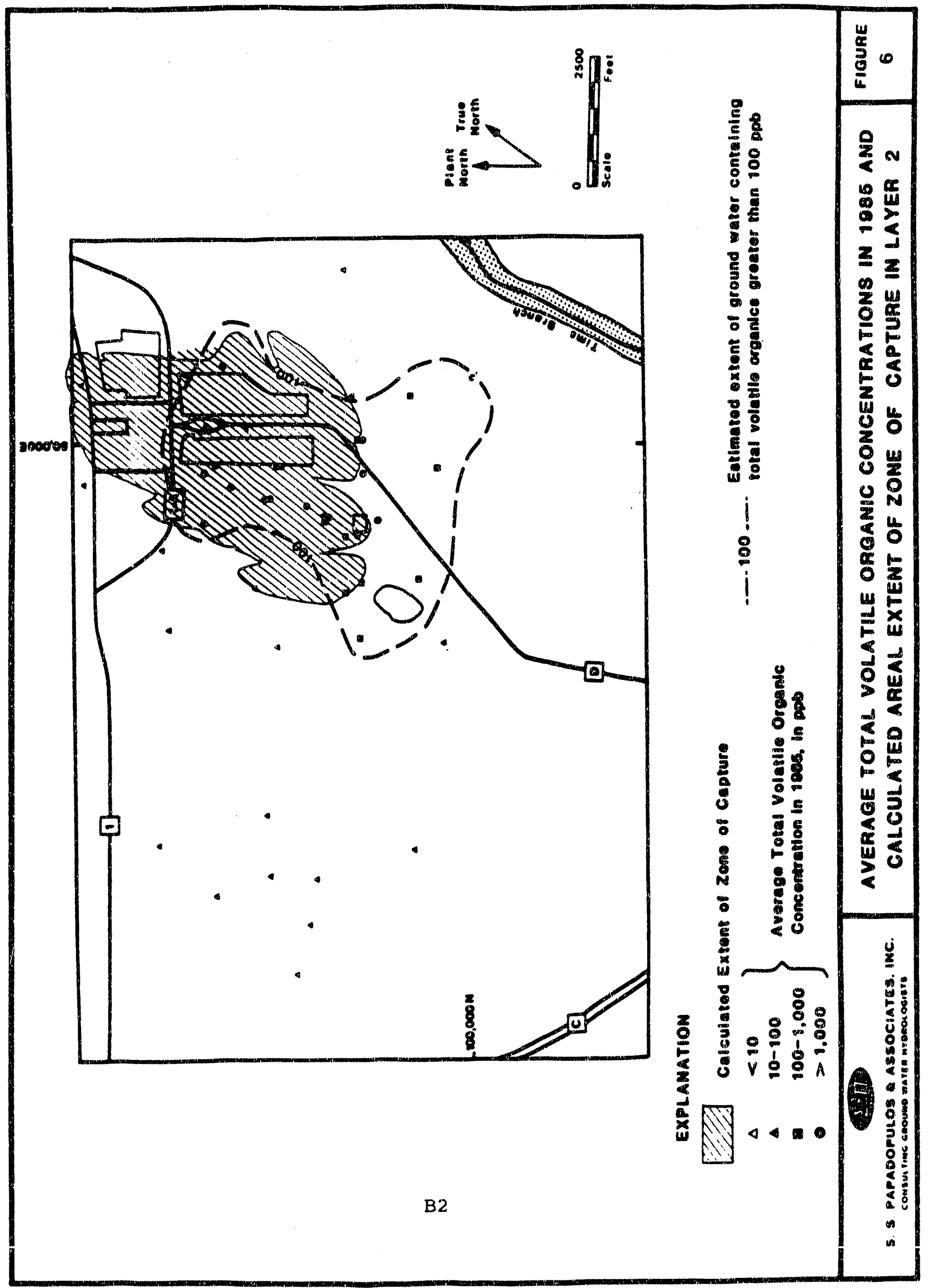




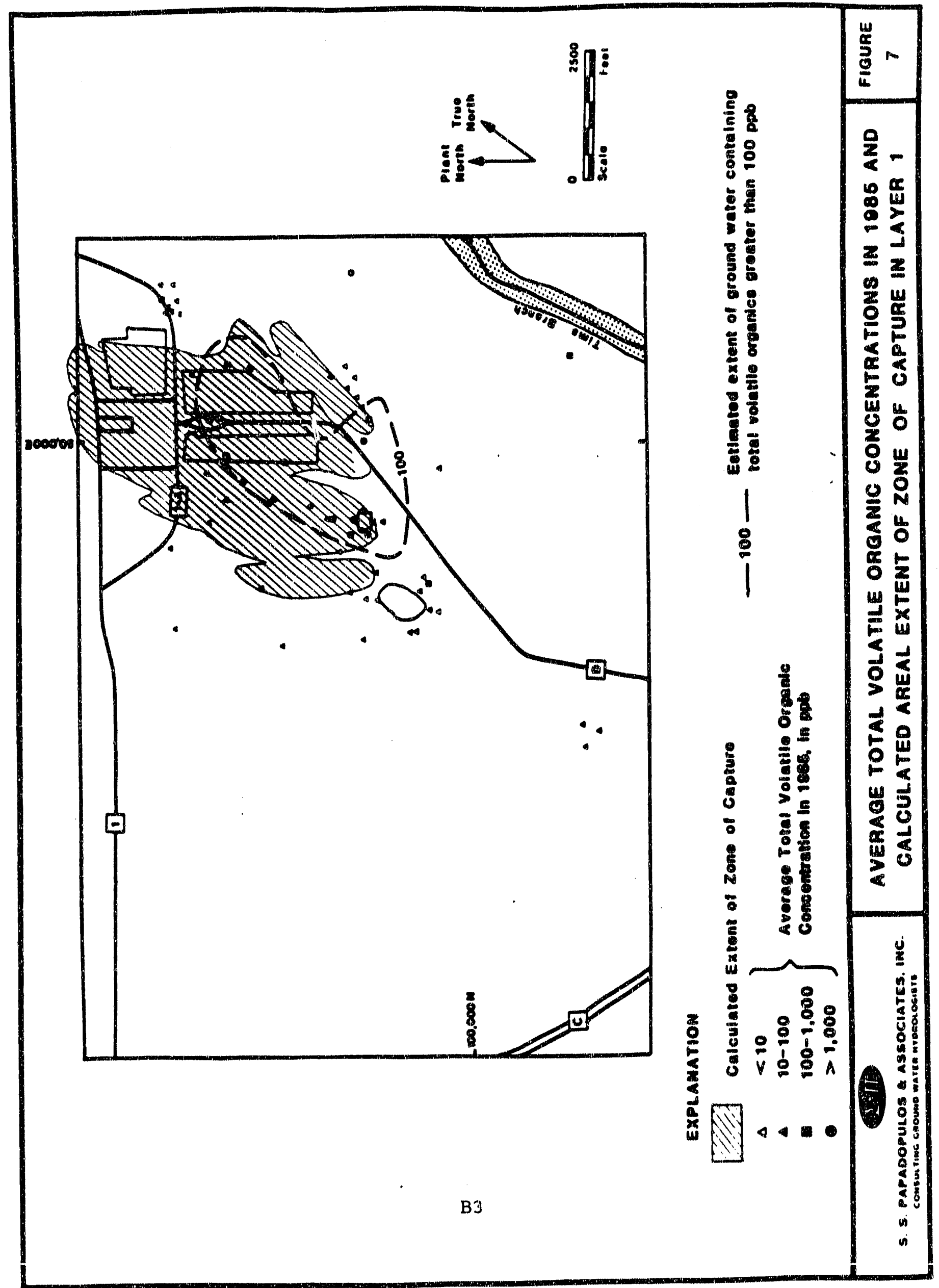



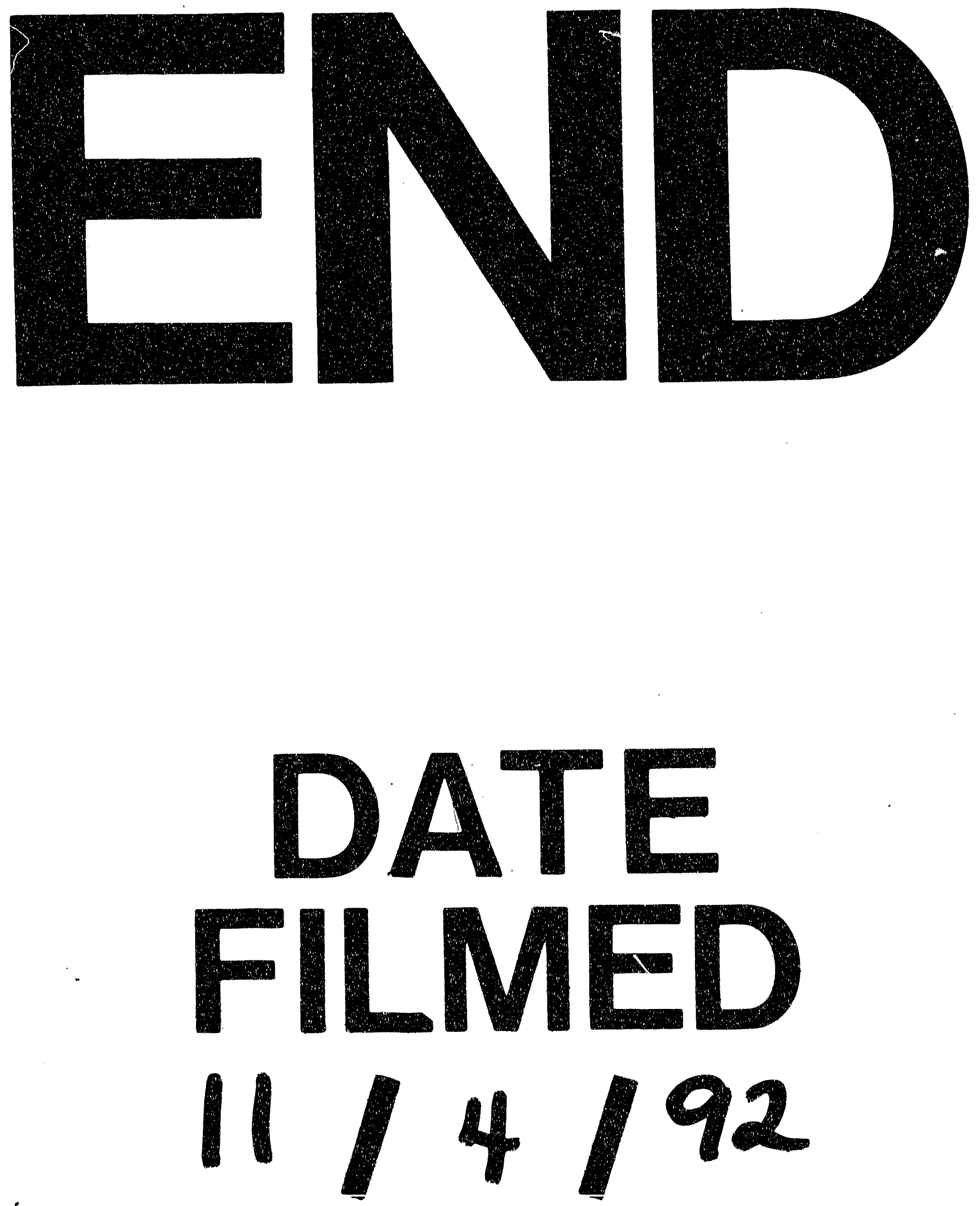

言 
